\title{
Board Composition, Firm Characteristics, and Voluntary Disclosure: The Case of Jordanian Firms Listed on the Amman Stock Exchange
}

\author{
Iaad I. S. Mustafa Sartawi ${ }^{1}$, Riyad M. Hindawi ${ }^{2}$, Ruba Bsoul ${ }^{1} \&$ Ala'eddin Jamil Ali ${ }^{1}$ \\ ${ }^{1}$ Faculty of Economics \& Administrative Sciences, Yarmouk University, Irbid, Jordan \\ ${ }^{2}$ Institute of banking Studies, Amman, Jordan \\ Correspondence: Iaad I. S. Mustafa Sartawi, Faculty of Economics \& Administrative Sciences, Yarmouk \\ University, Irbid, 21163, Jordan. Tel: 962-2-724-4964. E-mail: sartawi@yu.edu.jo
}

Received: February 18, 2014

Accepted: March 8, 2014

Online Published: May 27, 2014

doi:10.5539/ibr.v7n6p67

URL: http://dx.doi.org/10.5539/ibr.v7n6p67

\begin{abstract}
This study examines the impact of board composition on the level of voluntary disclosure in the annual reports of listed Jordanian firms. Content analysis is used to collect the required data form the 2012-annual reports of 103 firms listed on the Amman Stock Exchange. Overall, the empirical evidence provided by the study is in line with the agency theory predictions. Furthermore, they have practical implications for firms and regulators in Jordan on the importance of the board of directors and voluntary disclosure as control mechanisms for mitigating the effect of the information asymmetries and agency problems. The study shows a moderate level of voluntary disclosure in the annual reports of Jordanian firms. However, insurance firms tend to disclose more voluntary information than industrial and services firms. Also, the results suggest that Jordanian firms with a high-level of board ownership concentration tend to keep the level of voluntary disclosure low. On the other hand, the presence of foreign directors on the board seems to influence, positively, the level of voluntary disclosure in Jordanian firms. Likewise, the proportion of the old directors on the boards in Jordanian firms is very high and is significantly associated with a higher level of voluntary disclosure.
\end{abstract}

Keywords: board composition, voluntary disclosure, listed firms, Amman stock exchange

\section{Introduction}

In their classical propositions of the perfect capital market, Modigliani and Miller $(1958,1963)$ assume that management act exclusively on behalf of shareholders. This implies, among other things, that management (insiders) and investors (outsiders) have the same information about the firm's future investment opportunities. Thus, there is no information asymmetry problem. However, Jensen and Mekling (1976) argue that the separation of ownership and control creates the agency problem, where management tends to set their personal interests ahead of those of investors. The agency problem leads to the information asymmetry problem due to the information superiority the management enjoys as insider. A self interested management may confiscate the value of outsiders' (shareholders' and/or bondholders') investments by awarding themselves more perquisites, investing in unprofitable projects, issuing more senior claims, etc. Myers and Majluf (1984) argue that information asymmetries gives rise to the adverse selection problem, which leads to misvaluing the firm's equity in the marketplace and causes a loss of wealth for existing shareholders. Consequently, if this problem is not fully resolved it can harm the functionality of the capital market (Akerlof, 1970). Therefore, appropriate monitoring mechanisms must be implemented to mitigate the influence of information asymmetries and agency problem (Jensen \& Meckling, 1976). Two mechanisms are suggested by Healy and Palepu (2001): transparency and monitoring. The transparency mechanism requires management to disclose relevant information to help the investors to evaluate whether the firm's resources have been managed in their best interest or not. Empirical evidence provided by Welker (1995) demonstrates that higher disclosure policy reduces information asymmetry. Bloomfield and Wilks (2000) show that higher-quality disclosure ensures investors pay a high price for shares. According to Heflin, Shaw, and Wild (2002) a firm with high-quality accounting disclosure enhances its market liquidity through reducing information asymmetries across traders.

The second mechanism is to, effectively; monitor the behavior and actions of management by the board of directors. Monks and Minow (1995) argue that board monitoring improves the quality of managers' decisions. According to Healy and Palepu (2001) board monitoring insures, that management behaves in the sense of 
increasing the shareholders' interests and discloses credible information. This is vital since management is less inclined to provide investors with full and fair information if disclosure is left to their discretion (Singhvi \& Desai, 1971). However, the effectiveness of the board monitoring is determined among other things by its composition (Mizruchi, 2004; Brick, Palmon, \& Wald, 2006). Therefore, the purpose of this study is to, empirically; investigate the relationship between board composition and the level of voluntary disclosure in the annual reports of Jordanian firms listed on Amman Stock Exchange (ASE).

Examining the impact of board monitoring on voluntary disclosure is of a great relevance for the capital market in a developing country like Jordan. The capital market in Jordan is described as being imperfect, thin, and small. Management ownership is less than 4\% (ASE, 2005). Accordingly, agency cost and information asymmetries problems in such market are expected to be sever. These problems, if not resolved, may hinder the efficient allocation of resources in the market. Transparency through voluntary disclosure and board monitoring plays an important role in mitigating the impact of these problems on the market. Furthermore, research on this topic is well established in developed countries. In contrast, there is a lacuna of studies as to whether the impact of board composition on voluntary disclosure is similar in developing countries like Jordan.

The current study is expected to contribute to the literature on voluntary disclosure and corporate governance in different ways. First, it demonstrates the applicability of voluntary disclosure theory in a developing country like Jordan. Second, it provides empirical evidence on a number of potential factors that induces voluntary disclosure in Jordan. Such evidence may help Jordanian regulators in evaluating the adequacy of the current mandatory disclosure regulations (requirements) in Jordan. Third, the study provides a portrayal of corporate boards in Jordan using a comprehensive measure of board composition. Understanding the board composition and their impact on voluntary disclosure provides evidence on the sufficiency of the board of directors' guidelines in the corporate governance code in Jordan.

The remainder of the study is organized as follows: section 2 provides a brief overview of related literature and hypotheses development, section 3 presents the research methodology, section 4 reports and discusses the results of the empirical model and testing the study's hypotheses, and in section 5 the summary and conclusion are presented.

\section{Related Literature and Hypotheses Development}

\subsection{Board Composition and Voluntary Disclosure}

Transparency through disclosure and board monitoring are potential solutions to mitigating the agency and asymmetric information problems (Healy \& Palepu, 2001). Disclosure is viewed as the best vehicle for communicating with investors (Ho \& Wong, 2001). Firm's discloses mandatory and voluntary information in their annual reports. Mandatory information is provided in accordance to laws, regulations, and adopted accounting standards (Cheng \& Courtenay, 2006). It is the minimum level of disclosure required by the market to make it possible for investors to evaluate the firms in the market. Thus, it may be considered as a lawful way to mitigate the information asymmetry problem (Balachandran \& Bliss, 2004). On the other hand, voluntary disclosure refers to the additional information disclosed beyond what is required by law. It aims to provide investors with a clear picture about the economic realities of the firm (Boesso \& Kumar, 2007) and solve the information asymmetry problem (Healy \& Palepu, 2001). The lack of adequate disclosure can create ignorance in the market, which increase the information asymmetry problem (Baumol \& Bowman, 1965). Furthermore, in the absence of sufficient information, investment decisions are based on subjective rather than objective measures, which lead to fluctuations in the shares' prices in the market. In addition, firms may face difficulties in obtaining capital to finance their operations or they may incur higher cost of capital (Singhvi \& Desai, 1971).

Different theories attempt to explain voluntary disclosure by firms. For example, the agency theory assumes that firms disclose voluntary information to mitigate the agency problem through reducing the agency costs and to demonstrate that they are effectively utilizing the firm's resources in the best interest of shareholders (Barako, Hancock, \& Izan, 2006). According to the signaling theory, voluntary information helps firms to discriminate their performance from other firms (Campbell, Shrives, \& Saager, 2001), enhance their reputation, and attract new investments (Verrecchia, 1983). The capital need theory suggests that more voluntary disclosure enables firms to obtain the funds they need at lower cost (Choi, 1973). In spite of the importance of voluntary disclosure, it is left to the management's discretion (Chen \& Jaggi, 2000) and therefore, is influenced by their information-biased selection (Einhorn \& Ziv, 2012). Management decides on the type and amount of voluntary information to be disclosed in the firm's annual report (Eng \& Mak, 2003). Therefore, the presence of the board of directors in the firm is crucial for monitoring the managements' decisions and insuring that they disclose credible rather than self-serving voluntary information (Healy \& Palepu, 2001). This will help the firm to build a 
sound corporate disclosure system in the long run (Qu \& Leung, 2006).

Board of directors is elected by the firm's shareholders to govern and manage its affairs (Monks \& Minow, 2008). As a primary corporate governance mechanism it plays an essential role in aligning management's interests with those of the shareholders (Brennan, 2006) and reducing the agency and information asymmetry problems (Patelli \& Prencipe, 2007). However, the effectiveness of the board monitoring is determined among other things by its composition (Mizruchi, 2004; Brick, Palmon, \& Wald, 2006). Therefore, board composition is expected to affect the level of voluntary disclosure. Board composition can be defined in various perspectives, including value system, nationality, gender, board size, industry background, etc. (Van der Walt, Ingley, Shergill, \& Townsend, 2006; Kang, Cheng, \& Gray, 2007). However, in the current study the "board composition" includes the following perspectives: board size, board independence, board ownership concentration, institutional ownership, foreign ownership, member's age, and gender. These perspectives and their impact on voluntary disclosure are discussed in the next section.

\subsection{Hypotheses Development}

\subsubsection{Board Size}

Monitoring and controlling management actions are the most important functions of the board of directors (Fama \& Jensen, 1983). According to Gandia (2008) increasing the number of board members improves the capability of the board in monitoring and controlling management actions. This enhances the transparency and the disclosure of more information by management. Adam, Almeida, and Ferreira (2005) argue that larger boards have varied experiences and dispersed opinions. This, in turn, increases their monitoring capacities, and enhances the firm's disclosure policies. Empirical evidence reported by Cheng and Courtenay (2006) suggests that larger boards tend to be associated to greater levels of information disclosure. It worth noting that the corporate governance code for publicly listed firms in Jordan, recommends a board with more than five members and less than fifteen for the industrial and services sectors (Jordan Securities Commission, 2009). However, for the insurance sector the code recommends a board not less than seven members (Insurance Regulatory Commission, 2006). The previous discussion leads to the following hypothesis:

H1: There is a significant positive relationship between board size and the level of voluntary disclosure in the annual reports of Jordanian firms listed on ASE.

\subsubsection{Proportion of Non-Executive Directors}

Non-executive directors are board members who are not employed by the firm. They are viewed as a control mechanism as they perform an independent monitoring function (Patelli \& Prencipe, 2007). Their presence on the board could control the agency problem and reduce the information asymmetry between management and shareholders by providing more voluntary disclosure (Lim, Matolcsy, \& Chow, 2007). Recent studies show that the higher proportion of non-executive directors on boards, the more information they would like to disclose to outside investors. For example, Ajinkya, Bhojraj, and Sengupta (2005) report that companies with more non-executive directors are more likely to give a forecast in their annual reports. Cheng and Courtenay (2006) provide further evidence that firms with a higher proportion of non-executive directors have significantly higher levels of voluntary disclosure than firms with balanced boards. In Jordan, the Code of Corporate Governance recommends that at least one third of the board members to be independent (Jordan Securities Commission, 2009). The previous discussion leads to the following hypothesis:

$\mathrm{H} 2$ : There is a significant positive relationship between the proportion of non-executive board members and the level of voluntary disclosure in the annual reports of Jordanian firms listed on ASE.

\subsubsection{Duality of CEO and Chairman Positions}

Duality of CEO and chairman positions means that the person who serves as a chief executive officer (CEO) is the same person who serves as the chairman of the board of directors. This is a critical aspect of corporate governance since it may distort the board independence and reduces the effectiveness and efficiency of the board monitoring and controlling capabilities (Jensen, 1993; Khanchel, 2007). Role duality concentrates the power of managing business affairs in the hands of a single individual (Ho \& Wong, 2001; Gul \& Leung, 2004). This may reduce the quality and quantity of the information disclosed and consequently raises the information asymmetries problem (Li, Pike, \& Haniffa, 2008). According to Finkelstein, Hambrick, and Cannella (2009) the combination of the role of CEO and chairman is an indicator of CEO power over a board. This suggests that role duality reduces the board's ability to effectively control management, which consequently lowers the level of disclosure. Empirical results reported by Ho and Wong, (2001); Gul and Leung, (2004); Donnelly and Mulcahy, (2008) found a significant negative relationship between CEO duality and voluntary disclosure. The previous 
discussion leads to the following hypothesis:

H3: There is a significant negative relationship between Duality of CEO and chairman positions and the level of voluntary disclosure in the annual reports of Jordanian firms listed on ASE.

\subsubsection{Board Ownership Concentration}

Akhtaruddin and Haron (2012) discuss the effect of ownership concentration on voluntary disclosure. They argue that ownership concentration reflects the influence of the majority shareholders. A major shareholder can acquire information either through his position as a board member or directly from informal channels. Thus, the need for additional disclosure decreases when the level of board ownership concentration is high. Chau and Gray (2002) indicate that wider ownership is positively related to voluntary disclosure. Similar results are reported by other studies such as: Barako, Hancock, and Izan (2006); Xiao and Yuan (2007); Lim, Matolcsy, and Chow (2007). The previous discussion leads to the following hypothesis:

H4: There is a significant negative relationship between board ownership concentration and the level of voluntary disclosure in the annual reports of Jordanian firms listed on ASE.

\subsubsection{Institutional Ownership}

Institutional investors are viewed as an important governance mechanism. They have greater ability than scattered investors to monitor management behavior (Shleifer \& Vishny, 1997). In addition, they play an important role in aligning management interests with those of the shareholder (Solomon, 2010). Institutional investors are very rigorous about the quality and timing of the information they demand (Healy \& Palepu, 2001). Because of the large stake they own in the firm, they have the motivation to monitor the management's behavior (Jensen, 1993). Thus, they can compel management to improve the firm's reporting system to meet their expectations. Empirically, Carson and Simnett (1997) find a significant positive relationship between the institutional ownership and voluntary disclosure. Similar results are reported by Bushee and Noe (2000), Barako, Hancock, and Izan (2006). The previous discussion leads to the following hypothesis:

H5: There is a significant positive relationship between institutional ownership and the level of voluntary disclosure in the annual reports of Jordanian firms listed on ASE.

\subsubsection{Foreign Ownership}

Several studies investigated the impact of foreign ownership as a governance mechanism, and voluntary disclosure. They argue that foreign ownership may enhance the firm's corporate reporting practices (Singhvi \& Desi, 1971; Leuz, Lambert, \& Verrecchia, 2007; Haat, Abdul Rahman, \& Mahenthiran, 2008). Due to the geographical barriers, foreign investors are likely to face a higher level of information asymmetry compared with their domestic counterparts (Oxelheim \& Randoy, 2003). Accordingly, foreign investors tend to invest more in firms that disclose more information (Mangena \& Tauringana, 2007; Bokpin \& Isshaq, 2009). To reduce information asymmetry between foreign and domestic investors, firms are inclined to provide more information (Mangena \& Tauringana, 2007). Singhvi and Desi (1971) argue that the presence of foreign directors on the board may significantly influence the firm's financial reporting system to meet their requirements. Through their ownership power and voting rights foreign investors may encourage management to disclose more information (Adam, Almeida, \& Ferreira, 2005). Empirically, Haniffa and Cooke (2002) report a significant positive relationship between foreign ownership and the level of voluntary disclosure. Similar results are reported by Barako, Hancock, and Izan (2006); Barako (2007); Xiao and Yuan (2007); and Dhouibi and Mamoghli (2013). The previous discussion leads to the following hypothesis:

H6: There is a positive significant relationship between foreign ownership and the level of voluntary disclosure in the annual reports of Jordanian firms listed on ASE.

\subsubsection{Director's Age}

Corporate board is responsible for monitoring management decisions and behaviors. Their emphasis is on adding value through aligning the interests of managements and investors (Fama \& Jensen (1983). However, their effectiveness in playing this role is influenced, amongst other things, by the directors' personal characteristics such as gender, age, education and experience, to name few (Campbell \& Minguez-Vera, 2008; Ahern \& Dittmar, 2012). Age represents the extent of the individual's experience and risk-taking manner (Herrmann \& Datta, 2005). Accordingly, it can be assumed that older directors, with their cumulative experience, may have a substantial impact on the firm's performance (Hambrick \& Mason, 1984; Reed \& Defillippi, 1990). Empirically, existing evidence does not provide support in favor of older age. Rather, it reports that younger directors outperform older ones (e.g., Hambrick \& Mason, 1984; Sonnenfeld, 2002; Rose, 2005; Nakano \& Nguyen, 
2011). One possible explanation is that young directors are more open to change (Hambrick \& Mason, 1984) and new ideas (Zajac \& Westphal, 1996). Furthermore, they are more risk-taker, more innovative, and more efficient in governance oversight (Grimm \& Smith, 1991). It worth noting that the Jordanian Companies Law No. 22 of 1997 and its amendments impose a minimum restriction on the age of the board member. According to Article (147), a board member should be at least 21 years old (Ministry of Industry \& Trade, 2010). The previous discussion leads to the following hypothesis:

H7: There is a significant negative relationship between director's age and the level of voluntary disclosure in the annual reports of Jordanian firms listed on ASE.

\subsubsection{Director's Gender}

Gender diversity has developed to be one of the challenging research issues as the numbers of women in top management as well as on corporate board increases (Singh, Vinnicombe, \& Johnson, 2001). Gender diversity may benefit the board's decision making process. New perceptions are presented, and ideas are mutually exchanged (Alvarez \& McCaffery, 2000). Furthermore, diversity may become a competitive advantage because it enriches the board's knowledge base, creativity and innovation (Watson, Kumar, \& Michaelsen, 1993). Gibbins, Richardson, \& Waterhouse, (1992) argue that board gender diversity may explain the disclosure practices of the firms in their annual reports. Empirical results reported by Huse \& Solberg (2006) suggest that women directors are more interested for meetings than men. Therefore they are more likely to take good decisions. Adam \& Ferriera (2008) report that female directors have strong effect on board input and output. Furthermore, they have better attendance records than male, and are more likely to join monitoring committees. Their results suggest that gender-diverse boards allocate more effort to monitoring. The previous discussion leads to the following hypothesis:

H8: There is a positive significant relationship between director's gender and the level of voluntary disclosure in the annual reports of Jordanian firms listed on ASE.

\section{Method}

For the purpose of estimating the research model for hypotheses testing, a sample of Jordanian firms listed on the Amman Stock Exchange at the end of 2012 is selected. Content analysis is used to collect the required data from the annual reports of the sampled firms. The research model is estimated using OLS method on the cross-sectional data.

\subsection{Sample}

The population of the study includes all Jordanian firms listed on ASE. A total of 277 firms were listed on ASE at the end of 2012 (ASE, 2013). However, the sample of the study includes the firms that meet the following criteria:

- The firm should be listed on ASE for, at least, five years prior to the study.

- Firms ever going through consolidation, bankruptcy, or reorganization five years prior to the study are excluded to avoid biased results due to the effect of these events on the type and amount of information disclosed in their annual reports.

- Firms with unavailable data are excluded.

- Banks are excluded from the current study due to the nature of their business, and their special controlling and monitoring requirements and regulations.

Applying these criteria resulted in a sample composed of 103 firms. These firms belong to three major sectors as shown in Table 1. Furthermore, Table 2 shows summary demographic-statistics for the sampled firms.

Table 1. The distribution of the sample on the three sectors

\begin{tabular}{lcc}
\hline Sector & Number of firms & Percentage \\
\hline Industrial & 47 & $46 \%$ \\
Service & 39 & $38 \%$ \\
Insurance & 17 & $16 \%$ \\
Total & 103 & $100 \%$ \\
\hline
\end{tabular}


Table 2. Summary demographic statistics for the sampled firms

\begin{tabular}{lcccc}
\hline Sector & Min. & Max & Mean & S.D \\
\hline Size (JD) & 500,000 & $1,080,000,000$ & $62,000,000$ & $160,000,000$ \\
Leverage & 0.6 & 0.71 & 0.33 & 20.47 \\
ROE & -0.37 & 0.45 & 0.03 & 0.12 \\
\hline
\end{tabular}

According to Table 2, the sampled firms vary in their size with average total assets of approximately $\$ 62$ million. On average, these firms have a leverage percentage of approximately $33 \%$. Their profitability measured by the ROE ranges between $-37 \%$ and $45 \%$. In addition, the financial statements of almost $40 \%$ of these firms are audited by one of the big-4 auditing firms.

\subsection{Variables and Model}

\subsubsection{Measurement of the Dependent Variable}

Voluntary disclosure is the dependent variable in the current study. A refined version of the disclosure index developed by Lim, Matolcsy, \& Chow (2007) is used to measure voluntary disclosure in the annual reports of Jordanian firms. The refinement process is performed in three stages. Firstly, the index is compared with the Jordanian financial reporting laws and regulations (the companies' law, the instructions of issuing companies disclosure, accounting and auditing standards, and the corporate governance code for shareholding companies listed on the ASE). As a result, items that appeared to be mandatory are excluded from the index. Secondly, to reduce the subjectivity of the index, items are carefully reviewed and checked against the content of the annual reports of three Jordanian firms from the industrial, service and insurance sectors. Those items that appeared to be sector-specific are excluded. Thirdly, to keep the index simple, a total of 15 items are selected - amongst the remaining items - to be included in the final version of the refined index. Variety of item types is carefully considered during the selection process. Accordingly, the selected items reflect historical and forward looking information, quantitative and qualitative information, and financial and non-financial information. Lastly, a group composed of five certified auditors is asked to review and assess the selected items. Their comments and suggestions are taken into account and the index is modified accordingly. A dichotomous procedure is used to compute a disclosure score for each firm. Each disclosure item is assigned a score of 1 if it is disclosed and 0 if it is not disclosed. The voluntary disclosure index is calculated as the total items disclosed by the firm divided by 15 (the maximum possible score for the firm).

\subsubsection{Measurement of the Independent and Control Variables}

Board composition is the independent variable in the current study. It includes the following perspectives: board size, board independence, board ownership concentration, institutional ownership, foreign ownership, director's age, and gender. Following the stream of previous studies, a number of firm characteristics are investigated as control variables. These include: firm size, firm business sector, financial leverage, profitability, and type of audit firm. The definitions of these variables are presented in Table 3.

Table 3. The definitions and proxies of the independent variables

\begin{tabular}{ll}
\hline Variable & Definition/Proxy \\
\hline Board size & The number of directors on the board \\
Board Independence & Measured by two proxies: \\
& - The proportion of non-executive directors to total number of board members \\
Board ownership concentration & - Duality of CEO and chairman positions (Dummy variable: $1=$ duality, $0=$ no duality) \\
Institutional ownership & The percentage of shares outstanding held by the board of directors \\
& Measured by two proxies: \\
& - Percentage of institutional ownership \\
Foreign ownership & - Percentage of directors representing institutional shareholders on the board. \\
& Measured by two proxies: \\
& - Percentage of foreign ownership \\
& - The percentage of non-Jordanian directors on the board \\
\hline
\end{tabular}




\begin{tabular}{ll}
\hline Director's age & Average age of directors \\
Director's gender & Percentage of female directors \\
Firm size & Log of the firm's total assets \\
Firm's Business Sector & Dummy variable: $0=$ insurance sector, $1=$ other sectors \\
Financial leverage & Ratio of non-current liabilities to shareholder's equity \\
Profitability & Return on assets \\
Audit firm & Dummy variable: $0=$ Big- 4 audit firm, $1=$ other audit firms \\
\hline
\end{tabular}

\subsubsection{Model Development}

The following model is estimated to examine the relationship between board composition and the level of voluntary disclosure in the annual reports of Jordanians firms listed on ASE:

$$
\begin{gathered}
D I S C=\beta_{0}+\beta_{1} B O D S+\beta_{2} N E X D+\beta_{3} D U A L+\beta_{4} B O W N+\beta_{5} I N S T+\beta_{6} F O R G+\beta_{7} A G E+\beta_{8} G E N D \\
+\beta_{9} S I Z E+\beta_{10} S E C T+\beta_{11} F L E V+\beta_{12} P R O F+\beta_{13} A U D T+\varepsilon
\end{gathered}
$$

Where:

$\begin{array}{ll}\text { DISC } & \text { Voluntary disclosure; } \\ \text { BODS } & \text { Board size; } \\ \text { NEXD } & \text { Proportion of non-executive directors; } \\ \text { DUAL } & \text { Duality of CEO and chairman positions; } \\ \text { BOWN } & \text { Board ownership concentration; } \\ \text { INST } & \text { Institutional ownership; } \\ \text { FORG } & \text { Foreign ownership; } \\ \text { AGE } & \text { Director's age; } \\ \text { GEND } & \text { Director's gender; } \\ \text { SIZE } & \text { Firm size; } \\ \text { SECT } & \text { Firm business sector; } \\ \text { FLEV } & \text { Firm financial leverage; } \\ \text { PROF } & \text { Firm profitability; } \\ \text { AUDT } & \text { Auditing firm; } \\ \varepsilon & \text { Error term }(0, \sigma 2) ; \\ \beta_{\mathrm{k}} & \text { Regression coefficients. }\end{array}$

\subsection{Data Collection}

The data needed to carry out the current study are collected from the sampled firms' 2012-annual reports as well as the companies guide for publicly held corporations available at ASE site. Content analysis is used to extract the required data from the annual reports and the companies guide.

\section{Results}

\subsection{Level of Voluntary Disclosure}

Overall, the sampled firms show a moderate level of voluntary disclosure in their annual reports. The voluntary disclosure ranges between $27 \%$ and $86 \%$ with an average of $60 \%(\mathrm{SD}=.14)$. This level is higher than what has been reported by other studies conducted in different countries such as: Lim, Matolcsy, \& Chow (2007); Clemente \& Labat (2009); Yanesari, Gerayli, Ma'atoofi, \& Abadi (2012); Barros, Boubaker, \& Hamrouni (2013); Chakroun (2013); and Uyar, Kilic, \& Bayyur (2013). On average, firms disclose voluntarily more financial information (.72) than strategic (.58) and social responsibility (.49) information. This may be explained by the quantitative nature of financial information which makes it easily verifiable and thus, more useful for investors (Bozzolan, Trombetta, \& Beretta, 2009). In addition, the result shows a variation in the level of voluntary disclosure among business sectors. The insurance sector tends to voluntarily disclose more information than the industrial and service sectors. The average scores for these sectors are 63\% ( $\mathrm{SD}=.15), 49 \%(\mathrm{SD}=.13)$, and $44 \%$ 
$(\mathrm{SD}=.18)$ respectively. These results imply that there is a room for further improving voluntary disclosure practices in all categories and business sectors in Jordan.

\subsection{Composition of Corporate Boards in Jordanian Firms Listed on ASE}

Table 4 shows summary statistics for the boards' composition in Jordanian firms. According to the table, the average board size in Jordanian firms ranges between 5 and 13 directors with an average size of approximately 8 directors. Similar results are found in the industrial and service sectors. However, in the insurance sector the average board size is approximately 9 directors. The average age of directors is approximately 57 years with the majority of them (89\%) above 40 years old. These members can be described as mature and responsible (1). Moreover, these boards reflect a male-dominated culture where female directors range between 0 and 3 directors with an average of 1.3 directors. Overall, female directors in the sampled firms constitute only 5\% of the total directors and belong, only, to the service sector. Non-executive Directors represents 35\% to $92 \%$ of these boards with an average of $88 \%$. Duality of the CEO and chairman positions is found in $14 \%$ of the boards. Accordingly, these boards can be described as being highly independent. On the other hand, board ownership concentration is approximately $53 \%$, with the lowest concentration $40 \%$ in the insurance sector and the highest concentration $74 \%$ in the industrial sector. On average, institutional ownership ranges between $1 \%$ and $97 \%$ with an overall average of approximately 45\%. The directors representing institutional investors constitute $51 \%$ of total directors. Foreign ownership ranges between $0 \%$ and $95 \%$, with an overall average of approximately $35 \%$. Furthermore, the presence of foreign directors on these boards ranges between 0 and 9 directors with an average of 1.17 directors. Overall, foreign directors represent $23 \%$ of the total directors in the sampled firms.

Table 4. Summary statistics of corporate boards' characteristics in Jordanian firms

\begin{tabular}{lcccc}
\hline Sector & Min. & Max & Mean & S.D \\
\hline BODS & 5 & 13 & 8 & .2 \\
NEXD & .35 & .92 & .88 & .16 \\
BOWN & .09 & .99 & .53 & .22 \\
INST & .01 & .97 & .45 & .31 \\
FORG & 0 & .95 & .35 & .24 \\
AGE & 28 & 83 & 57 & .94 \\
\hline & Female & Male & \\
GEND & .05 & .95 & & \\
DUAL & Combine & Separate & & \\
\hline
\end{tabular}

\subsection{Board Composition and Voluntary Disclosure}

Multiple regression analysis relies upon a number of classical assumptions. Before running the regression analysis, these assumptions have to be examined. The descriptive analysis presented in sections 3.1 and 4.2 shows dispersion in some independent variables. The appropriate functions are used to transform these variables in order to reduce their disparity. The result of the bivariate correlation analysis between independent variables shows that the highest value of the Pearson correlation coefficients (r) is 0.518 . This indicates that there is no apparent evidence on the presence of severe multicollinearity amongst the independent variables (Berry \& Feldman, 1985). A summary of the results of the regression analysis performed on the model is presented in Table 5.

According to Table 5, the model has an adjusted $\mathrm{R}^{2}$ of 0.276 . This means that the model explains almost $28 \%$ of the variation in the voluntary disclosure amongst sampled firms. Furthermore, the high probability of the $\mathrm{F}$ statistic (.000) means that the independent variables are jointly significant in explaining voluntary disclosure in the annual reports of the sampled firms. The VIF test suggests that the model does not suffer from any multicollinearity problem where the VIF of all variables ranges between 1.03 and 1.28 . On the other hand, the Breusch-Pagan-Godfrey test is found to be statistically significant $\left(\mathrm{Chi}^{2}=0.09, \rho=0.0419\right)$. This implies that the homoskedicity assumption is violated (Gujarati, 2003). Fortunately, Stata 11 corrects the model's results to adjust for hetroskedicity. 
Table 5 shows a positive relationship between the size of the board of directors BODS and the level of voluntary disclosure. $(\beta=.003, \rho=.874)$. This means that as more directors are added to the board, its monitoring capacity increases and thus more voluntary information is disclosed. However, the relationship is found to be insignificant. Therefore, Hypothesis 1 is not supported. This implies that the quality of the board monitoring is a function of efficiency rather than size (Uyar, Kilic, \& Bayyur, 2013). As explained by John \& Senbet (1998) it seems that the incremental cost of poor communication outweighs the benefit of adding a new director to the board.

Table 5 also shows that the coefficient of NEXE is positive as expected $(\beta=.510)$. However, statistically, it is insignificant $(\rho=.720)$. Thus Hypothesis 2 is not supported. This implies that non-executive directors in Jordanian firms, like in other developing countries, are not truly independent (Barako, Hancock, \& Izan, 2006). They may have strong family, business, or friendship relations with executive directors, which influence their independency and weaken their monitoring role.

Table 5. Summary of the regression results

\begin{tabular}{|c|c|}
\hline \multicolumn{2}{|c|}{ Dependent variable: DISC } \\
\hline Independent variables & Final Model $^{1}$ \\
\hline \multirow[t]{2}{*}{ BODS } & .003 \\
\hline & $(.874)$ \\
\hline \multirow[t]{2}{*}{ NEXD } & .151 \\
\hline & $(.720)$ \\
\hline \multirow[t]{2}{*}{ DUAL } & -.069 \\
\hline & $(.496)$ \\
\hline \multirow[t]{2}{*}{ BOWN } & -.299 \\
\hline & $(.018)^{* *}$ \\
\hline \multirow[t]{2}{*}{ INST } & .067 \\
\hline & $(.539)$ \\
\hline \multirow[t]{2}{*}{ FORG } & .354 \\
\hline & $(.004) *$ \\
\hline \multirow[t]{2}{*}{ AGE } & .685 \\
\hline & $(.000)^{*}$ \\
\hline \multirow[t]{2}{*}{ GEND } & .068 \\
\hline & $(.465)$ \\
\hline \multirow[t]{2}{*}{ SIZE } & .037 \\
\hline & $(.250)$ \\
\hline \multirow[t]{2}{*}{ SECT } & -.162 \\
\hline & $(.024)^{* *}$ \\
\hline \multirow[t]{2}{*}{ FLEV } & .002 \\
\hline & $(.896)$ \\
\hline \multirow[t]{2}{*}{ PROF } & .078 \\
\hline & $(.781)$ \\
\hline \multirow[t]{2}{*}{ AUDT } & .052 \\
\hline & $(.479)$ \\
\hline Intercept & -.442 \\
\hline Adj $R^{2}$ & .286 \\
\hline F sig & .000 \\
\hline VIF & $1.03-1.28$ \\
\hline
\end{tabular}

Note. Numbers in brackets below the coefficient are the probability levels of significance.

${ }^{1}$ Corrected for hetroskedicity.

* Significant at 1\%,** Significant at 5\%. 
The table also shows that the coefficient estimate on DUAL is negative $(\beta=.069)$ but statistically insignificant at the .5 level $(\rho=.496)$. Therefore, Hypothesis 3 is not supported. This result is consistent with those of Ho \& Wong (2001), Hanifa \& Cooke (2002), Eng \& Mak (2003), Barako, Hancock, \& Izan (2006), Cheng \& Courtenay (2006), Li, Pike, \& Haniffa (2008), Yuen, Liu, Zhang, \& Lu (2009), Said, Hj Zainuddin, \& Haron (2009) who did not find a significant relationship between duality of CEO/Chairman positions and the level of disclosure.

Board ownership concentration BOWN has a significant negative relationships with voluntary disclosure ( $\beta=$ $-.299, \rho=.018$ ). This means that under a higher level of ownership concentration less voluntary information is disclosed. Thus Hypothesis 4 is supported. This finding is in line with what has been reported by other empirical studies (e.g., Eng \& Mak, 2003; Ben Ali, Trabelsi, \& Summa, 2009; Lakhal, 2007; Abdur Rouf \& Al Harun, 2011; Yanesari, Gerayli, Ma'atoofi, \& Abadi, 2012; Chakroun, 2013; Jahmani, 2013). Furthermore, it supports the argument that the presence of large shareholders encourages "information retention", since they can rely on internal sources for obtaining information (Banghøj \& Plenborg, 2008).

The effect of institutional ownership INST on the level of voluntary disclosure is found to be negative $(\beta=-.067)$ and insignificant $(\rho=.539)$. Accordingly, Hypothesis 5 is not supported. The unexpected direction of the relationship implies that institutional investors in Jordanian firms have no concern in voluntary disclosure either because they have access to the information in the firm (Chau \& Gray, 2002), or because their interest is not aligned with those of minority investors (Lim, Matolcsy, \& Chow, 2007).

Foreign investment FORG is found to be significantly positively associated with voluntary disclosure $(\beta=.354$, $\rho=.004)$. This finding supports Hypothesis 6 , and coincides with the empirical evidence reported by Haniffa \& Cooke (2002), Barako, Hancock, \& Izan (2006), Barako (2007), Mangena \& Turingana (2007), Xiao \& Yuan (2007), Wang, Sewon, \& Claibone (2008), Dhouibi \& Mamoghli (2013), Chakroun (2013) and Qu, Cooper, Wise, \& Leung (2012). In addition, it is consistent with the argument that firms tend to disclose more information to reduce the high level of information asymmetry faced by foreign investors (Mangena \& Turingana, 2007), and thus, attract more foreign investments. Furthermore, foreign investors could be effectively monitoring management and using their voting power to influence them to disclose more information (Adam, Almeida, \& Ferreira, 2005).

The relationship between director's age AGE and voluntary disclosure is found to be positive and highly significant $(\beta=.685, \rho=.000)$. This means that firms with corporate boards composed of older directors discloses more voluntary information in their annual reports. Thus, Hypothesis 7 is not supported. According to Sonnenfeld (2002) age is perceived as an asset since it reflects experience and maturity. Therefore, older directors are viewed as having more experience, greater independence, and long-term connections that lead to stronger corporate performance and transparency (Van Ness \& Seifert, 2007).

Director's gender GEND is found to be positively related to voluntary disclosure $(\beta=.086)$. This means that the more female directors on the board, the more information voluntarily disclosed by the firm. However, this relationship is statistically insignificant $(\rho=.465)$. Thus Hypothesis 8 is not supported.

Turning to the control variables, Table 5 shows that, amongst the 5 control variables, only business sector is found to be significantly associated with voluntary disclosure $(\beta=-.162, \rho=.024)$. The negative sign of the coefficient estimate suggests that insurance firms tend to provide more voluntary information than industrial and service firms. This result may be attributed to the fact that insurance sector in Jordan is subject to additional regulation and more severe internal control rules set by the Insurance Commission.

\section{Discussion and Concluding Remarks}

This study examines the impact of board composition on voluntary disclosure in the annual reports of Jordanian firms listed on the ASE. Multivariate regression is used to analyze the data collected from 103 firms listed on ASE at the end of 2012. The study also controls for those determinants of voluntary disclosure which have previously been documented in the literature.

Overall, the results of the study provides theoretical and practical implications on the importance of the board of directors and voluntary disclosure as control mechanisms for aligning the interests of management and share holders in order to mitigate the effect of the information asymmetries and agency problems. First, the study shows a moderate level of voluntary disclosure in the annual reports of Jordanian firms. This result provides additional evidence for Jordanian regulators that there is a room for further improving voluntary disclosure practices in Jordan. The amount of voluntary information disclosed by Jordanian firms in their annual reports varies according to the firm's business sector. Insurance firms tend to disclose more voluntary information than 
industrial and services firms. This may be attributed to the extensive monitoring and regulations imposed on the insurance sector not only by Jordan Securities Commission, but also by the Insurance Regulatory Commission. Furthermore, corporate governance code for insurance firms came into effect three years earlier than the code for the industrial and service firms. In addition, the nature of the insurance business that may be associated to higher risk may explain the higher level of voluntary information disclosed by insurance firms. Second, in line with the agency theory predictions, the study finds that Jordanian firms with a high-level of board ownership concentration tend to keep the level of voluntary disclosure low. This implies that corporate boards in Jordanian firms (controlling shareholders) are practicing what is called "information retention" to confiscate minority shareholders and make personal benefits. Therefore, Jordanian regulators need to protect the right of minority shareholders in obtaining information in order to reduce the effect of information asymmetries and agency problems.

Third, the presence of foreign directors on the board seems to influence, positively, the level of voluntary disclosure in Jordanian firms. This finding reinforces the fact that foreign investors tend to invest more in firms that disclose more information. Furthermore, it has some implications for Jordanian firms and Jordanian regulators. For example, firms seeking to attract foreign investments may need to improve the quality of their reporting systems. Regulators can help these firms by providing guidelines for appropriate voluntary disclosure practices. Fourth, the proportion of the old directors on the boards in Jordanian firms is very high and is significantly associated with a higher level of voluntary disclosure. It seems that the rich skills, greater experience, and long-term connections of these directors contribute to improving information transparency in Jordanian firms.

\section{Limitations and Future Research Opportunities}

The study has some limitations. Therefore, the results should be interpreted cautiously. First, the scope of the study is limited to the publicly listed firms in the industrial, service and insurance sectors which may not represent other firms such as banks. Thus, samples in future studies need to be expanded to include these firms. Additionally, the study focuses on Jordanian firms only. Therefore, conclusions drawn from this study cannot necessarily be applied to other countries. Future studies may focus on new countries. In addition, cross-country comparative studies can reveal interesting results on the differences in the determinants of voluntary disclosure level amongst different countries. Second, the study is based on a cross-sectional data set. In this way its findings relate to voluntary disclosure practices at a specific point in time. However, disclosure practices tend to change over time. Accordingly, different results may be obtained if another time-frame has been chosen. Therefore, the use of longitudinal data may reveal more reliable insights and trends into the determinants of voluntary disclosure. Moreover, the model in the current study implies several causal relations between the variables. However, a cross-sectional design does not allow testing causality directly. Thus, claims of causality are based on theoretical arguments. Third, the study focuses, only, on one channel for voluntary disclosure, that is; the annual reports. Future studies may consider other channels for disclosing information such as interim reports, firm's web page, the social media, and the press. The study investigates the influence of eight variables, only, on the level of voluntary disclosure. Therefore, future studies may consider other variables such as firm's culture, family directors on the board, audit committee, directors' education, experience, and knowledge. Furthermore, alternative proxies for measuring the independent variables as well as the dependent variable may be used.

\section{Acknowledgement}

The authors would like to acknowledge financial support from the Scientific Research Support Fund at Yarmouk University.

\section{References}

Abdur Rouf, M., \& Al Harun, A. (2011). Ownership structure and voluntary disclosure in annual reports of Bangladesh. Pakistan Journal of Commerce and Social Sciences, 5(1), 129-139.

Adam, R., Almeida, H., \& Ferreira, D. (2005). Powerful CEOs and their impact on corporate governance. The Review of Financial Studies, 18(4), 1403-1432. http://dx.doi.org/10.1093/rfs/hhi030

Adams, R., \& Ferreira, D. (2008). Do directors perform for pay? Journal of Accounting and Economics, 46, 154-171. http://dx.doi.org/10.1016/j.jacceco.2008.06.002

Ahern, K., \& Dittmar, A. (2012). The changing of the boards: The impact on firm valuation of mandated female board representation. Quarterly Journal of Economics, 1, 137-197. http://dx.doi.org/10.1093/qje/qjr049

Ajinkya, B., Bhojraj, S., \& Sengupta, P. (2005). The association between outside directors, institutional investors and the properties of management earnings forecasts. Journal of Accounting Research, 43(3), 343-375. 
http://dx.doi.org/10.1111/j.1475-679x.2005.00174.x

Akerlof, G. (1970). The Market for 'lemons': Quality uncertainty and the market mechanism. Quarterly Journal of Economics, 84, 488-500. http://dx.doi.org/10.2307/1879431

Akhtaruddin, M., \& Haron, H. (2010). Board ownership, audit committees' effectiveness and corporate voluntary disclosures. Asian Review of Accounting, 18(1), 68-82. http://dx.doi.org/10.1108/13217341011046015

Alvarez, R., \& McCaffery, E. (2000). Is there a gender gap in fiscal political preferences? Social Science Working Paper. California Institute of Technology, Pasadena CA.

ASE. (2005). The seventh annual report. Research and External Relations Department, Amman, Jordan.

Assoyotee, J. (1982). Addur almanthoor fel tafseer bil ma 'thoor. Beurit: Dar Alfikr.

Balachandran, J., \& Bliss, M. (2004). Board independence and voluntary disclosure: Evidence from Malaysia. Working Paper, Department of Accountancy, City University of Hong Kong.

Banghøj, J., \& Plenborg, T. (2008). Value relevance of voluntary disclosure in the annual report. Accounting and Finance, 48(2), 159-180. http://dx.doi.org/10.1111/j.1467-629X.2007.00240.x

Barako D., Hancock, P., \& Izan, H. (2006). Factors influencing voluntary corporate disclosure by Kenyan firms. Corporate Governance: An International Review, 14(2), 107-125. http://dx.doi.org/10.1111/j.1467-8683.2006.00491.x

Barako, D. (2007). Determinants of voluntary disclosures in Kenyan companies annual reports. African Journal of Business Management, 1(5), 113-128.

Barros, C., Boubaker, S., \& Hamrouni, A. (2013). Corporate Governance and Voluntary Disclosure in France. The Journal of Applied Business Research, 29(2), 561-578.

Baumol, W., \& Bowen, W. (1965). On the performing arts: The anatomy of their economic problem. American Economic Review, 55(1/2), 495-502.

Ben Ali, C., Trabelsi, S., \& Summa, M. (2009). Disclosure quality and ownership structure: Evidence from the French stock market. Journal of Corporate Ownership and Control, 5(2), 466-480.

Berry, W., \& Feldman, S. (1985). Multiple regression in practice. Sage University Paper Series on Quantitative Applications in the Social Sciences, series no. 07-050. Newbury Park.

Bloomfield, R., \& Wilks, T. (2000). Disclosure effect in the laboratory: Liquidity, depth, and the cost of equity capital. The Accounting Review, 75(1), 13-41. http://dx.doi.org/10.2308/accr.2000.75.1.13

Boesso, G., \& Kumar, K. (2007). Drivers of corporate voluntary disclosure: A framework and empirical evidence from Italy and the United States. Accounting, Auditing \& Accountability Journal, 20(2), 269-296. http://dx.doi.org/10.1108/09513570710741028

Bokpin, G., \& Isshaq, Z. (2009). Corporate governance, disclosure and foreign share ownership on the Ghana stock exchange. Managerial Auditing Journal, 24(6), 688-703. http://dx.doi.org/10.1108/02686900910975387

Bozzolan, S., Trombetta, M., \& Beretta, S. (2009) Forward-looking disclosures, financial verifiability and analysts' forecasts: A study of cross-listed European firms. European Accounting Review, 18(3), 435-473. http://dx.doi.org/10.1080/09638180802627779

Brennan, N. (2006). Boards of directors and firm performance: Is there an expectations gap? Corporate Governance: An International Review, 14(6), 577-593. http://dx.doi.org/10.1111/j.1467-8683.2006.00534.x

Brick, I., Palmon, O., \& Wald, J. (2006). CEO compensation, director compensation and firm performance: Evidence of cronyism? Journal of Corporate Finance, 12(3), 403-423. http://dx.doi.org/10.1016/j.jcorpfin.2005.08.005

Bushee, B., \& Noe, C. (2000). Corporate disclosure practices, institutional investors, and stock return volatility. Journal of Accounting Research, 38(Suppl), 171-202. http://dx.doi.org/10.2307/2672914

Campbell, D., Shrives, P., \& Saager, H. (2001). Voluntary disclosure of mission statements in corporate annual reports: signaling what and to whom? Business and Society Review, 106(1), 65-87. http://dx.doi.org/10.1111/0045-3609.00102

Campbell, K., \& Mínguez-Vera, A. (2008). Gender diversity in the boardroom and firm financial performance. Journal of Business Ethics, 83(3), 435-451. http://dx.doi.org/10.1007/s10551-007-9630-y 
Carson, E., \& Simnett, R. (1997). Voluntary disclosure of corporate governance information. Unpublished working paper, University of New South Wales, Sydney.

Chakroun, R. (2013). Family control, board of directors' independence and extent of voluntary disclosure in the annual reports: Case of Tunisian companies. Journal of Business Studies Quarterly, 5(1), 22-42.

Chau, G., \& Gray, S. (2002). Ownership structure and corporate voluntary disclosure in Hong Kong and Singapore. The International Journal of Accounting, 37(2), 247-265. http://dx.doi.org/10.1016/S00207063(02)00153-X

Chen, P., \& Jaggi, B. (2000). Association between independent non-executive directors, family control and financial disclosures in Hong Kong. Journal of Accounting and Public Policy, 19(4), 285-310. http://dx.doi.org/10.1016/S0278-4254(00)00015-6

Cheng, E., \& Courtenay, S. (2006). Board composition, regulatory regime and voluntary disclosure. The International Journal of Accounting, 41(3), 262-289. http://dx.doi.org/10.1016/j.intacc.2006.07.001

Choi, F. (1973). Financial disclosure and entry to the European capital market. Journal of Accounting Research, 11(2), 159-175. http://dx.doi.org/10.2307/2490187

Clemente, A., \& Labat, B. (2009). Corporate governance mechanisms and voluntary disclosure: The role of independent directors in the boards of listed Spanish firms. Journal of Financial Economics, 5, 243-270.

Dhouibi, R., \& Mamoghli, C. (2013). Determinants of voluntary disclosure in Tunisian bank's reports. Research Journal of Finance and Accounting, 4(5), 80-94.

Donnelly, R., \& Mulcahy, M. (2008). Board structure, ownership, and voluntary disclosure in Ireland. Corporate Governance: An International Review, 16(5), 416-429. http://dx.doi.org/10.1111/j.1467-8683.2008.00692.x

Einhorn, E., \& Ziv, A. (2012). Biased voluntary disclosure. Review of Accounting Studies, 17(2), 420-442. http://dx.doi.org/10.1007/s11142-011-9177-0

Eng, L., \& Mak, Y. (2003). Corporate governance and voluntary disclosure. Journal of Accounting and Public Policy, 22(4), 325-345. http://dx.doi.org/10.1016/S0278-4254(03)00037-1

Fama, E., \& Jensen, M. (1983). Separation of ownership and control. The Journal of Law and Economics, 26(2), 36-67. http://dx.doi.org/10.1086/467037

Finkelstein, D., Hambrick, A., \& Cannella, Jr. (2009). Strategic leadership: Theory and research on Executives, Top Management Teams, and Board. New York: Oxford University Press.

Gandia, J. (2008). Determinates of internet-based corporate governance disclosure by Spanish listed companies. Online Information Review Journal, 32(6), 791-817. http://dx.doi.org/10.1108/14684520810923944

Gibbins, M., Richardson, A., \& Waterhouse, J. (1990). The management of corporate financial disclosure: Opportunism, ritualism, policies, and process. Journal of Accounting Research, 28(1), 121-143. http://dx.doi.org/10.2307/2491219

Grimm, C., \& Smith, K. (1991). Management and organizational change: A note on the railroad industry. Strategic Management Journal, 12, 557-562. http://dx.doi.org/10.1002/smj.4250120708

Gujarati, D. (2003). Basic Econometrics (4th ed.). New York: McGraw Hill.

Gul, F., \& Leung, S. (2004). Board leadership, outside directors' expertise and voluntary corporate disclosures. Journal of Accounting and Public Policy, 23, 351-379. http://dx.doi.org/10.1016/j.jaccpubpol.2004.07.001

Haat, M., Abdul Rahman, R., \& Mahenthiran, S. (2008). Corporate governance, transparency and performance of Malaysian firms. Managerial Auditing Journal, 23(8), 744-778. http://dx.doi.org/10.1108/02686900810899518

Hambrick, D., \& Mason, P. (1984). Upper echelons theory: The organization as a reflection of its top managers. Academy of Management Review, 9(2), 193-343.

Haniffa, R., \& Cooke, T. (2002). Culture, corporate governance and disclosure in Malaysian corporations. ABACUS: Journal of Accounting, Finance and Business Studies, 38(3), 317-349. http://dx.doi.org/10.1111/1467-6281.00112

Healy, M., \& Palepu, G. (2001). Information asymmetry, corporate disclosure, and the capital markets: A review of the empirical disclosure literature. Journal of Accounting and Economics, 31(1-3), 405-440. http://dx.doi.org/10.1016/S0165-4101(01)00018-0 
Heflin, F., Shaw, K., \& Wild, J. (2002). Disclosure quality and market liquidity. Working Paper, Robert H. Smith School of Business, College Park, MD.

Herrmann, P., \& Datta, D. (2005). Relationships between top management team characteristics and international diversification: An empirical investigation. British Journal of Management, 16(1), 69-78. http://dx.doi.org/10.1111/j.1467-8551.2005.00429.x

Ho, S., \& Wong, K. (2001). A study of the relationship between corporate governance structure and the extent of voluntary disclosure. Journal of International Accounting, Auditing and Taxation, 10(1), 139-156. http://dx.doi.org/10.1016/S1061-9518(01)00041-6

Huse, M., \& Solberg, A. (2006). Gender-related boardroom dynamics: How Scandinavian women make and can make contributions on corporate boards. Women in Management Review, 21, 113-130. http://dx.doi.org/10.1108/09649420610650693

Insurance Regulatory Commission. (2006). Corporate governance instructions for insurance companies of 2006. Retrieved from http:// ww.irc.gov.jo

Jahmani, O. (2013). Ownership structure and corporate voluntary disclosure: Evidence from Bahrain. International Journal of Accounting and Financial Reporting, 3(2), 133-148. http://dx.doi.org/10.5296/ijafr.v3i2.4088

Jensen, M. (1993). The modern industrial revolution, exit and the failure of internal control systems. The Journal of Finance, 48(3), 831-880. http://dx.doi.org/10.1111/j.1540-6261.1993.tb04022.x

Jensen, M., \& Meckling, W. (1976). Theory of the firm: Managerial behavior, agency costs and ownership $\begin{array}{llll}\text { structure. Journal of } & \text { Financial 305-360. }\end{array}$ http://dx.doi.org/10.1016/0304-405X(76)90026-X

John, K., \& Senbet, L. (1998). Corporate governance and board effectives. Journal of Banking and Finance, 22(4), 371-403. http://dx.doi.org/10.1016/S0378-4266(98)00005-3

Jordan Securities Commission. (2009). Corporate Governance Code for Shareholding Companies Listed on the Amman Stock Exchange. Retrieved from http://www.jsc.gov.jo

Kang, H., Cheng, M., \& Gray, S. (2007). Corporate governance and board composition: Diversity and independence of Australian boards. The Journal of Corporate Governance, 15(2), 194-207. http://dx.doi.org/10.1111/j.1467-8683.2007.00554.x

Khanchel, I. (2007). Corporate governance: measurement and determinate analysis. Managerial Auditing Journal, 22(8), 740-760. http://dx.doi.org/10.1108/02686900710819625

Lakhal, F. (2007). Ownership structure and voluntary disclosures: the case of French-listed firms. Corporate Ownership and Control, 5(1), 131-138.

Leuz, C., Lambert, R., \& Verrecchia, R. (2007). Accounting information, disclosure and the cost of capital. Journal of Accounting Research, 45, 385-420. http://dx.doi.org/10.1111/j.1475-679X.2007.00238.x

Li, J., Pike R., \& Haniffa, R. (2008). Intellectual capital disclosure and corporate governance structure in UK firms. Accounting and Business Research, 38(2), 137-159. http://dx.doi.org/10.1080/00014788.2008.9663326

Lim, S., Matolcsy, Z., \& Chow, D. (2007). The Association between board composition and different types of voluntary disclosure. European Accounting Review, 16(3), 555-583. http://dx.doi.org/10.1080/09638180701507155

Mangena, M., \& Tauringana, V. (2007). Disclosure, corporate governance and foreign share ownership on the Zimbabwe stock exchange. Journal of International Financial Management and Accounting, 18(2), 53-85. http://dx.doi.org/10.1111/j.1467-646X.2007.01008.x

Ministry of Industry \& Trade. (2002). The companies law No. 22 of 1997 and its amendments. Retrieved from http://www.mit.gov.jo

Mizruchi, M. (2004). Berle and means revisited, the governance and power of U.S. corporations. Theory and Society, 33(5), 579-617. http://dx.doi.org/10.1023/B:RYSO.0000045757.93910.ed

Modigliani, F., \& Miller, M. (1958). The cost of capital, corporation finance and the theory of investment. American Economic Review, 48(3), 261-297.

Modigliani, F., \& Miller, M. (1963). Corporate income taxes and the cost of capital: a correction. American 
Economic Review, 53(3), 433-443.

Monks, R., \& Minow, N. (1995). Corporate Governance. Cambridge, Massachusetts: Blackwell.

Myers, S., \& Majluf, N. (1984). Corporate financing and investment decisions when firms have information that investors do not have. Journal of Financial Economics, 13(2), $187-221$. http://dx.doi.org/10.1016/0304-405X(84)90023-0

Nakano, M., \& Nguyen, P. (2011). Do older boards affect firm performance? An empirical analysis based on Japanese firms. The sixth annual conference on Asia-Pacific Financial Markets (CAFM) of the Korean Securities Association, Seoul, Korea, December 2, 2011.

Oxelheim, L., \& Randoy, T. (2003). The impact of foreign board membership on firm value. Journal of Banking and Finance, 27(12), 2369-2392. http://dx.doi.org/10.1016/S0378-4266(02)00395-3

Patelli, L., \& Prencipe, A. (2007). The relationship between voluntary disclosure and independent directors in the presence of a dominant shareholder. European Accounting Review, 16(1), 5-33. http://dx.doi.org/10.1080/09638180701265820

Qu, W., \& Leung, P. (2006). Culture impact on Chinese corporate disclosure-a corporate governance perspective. Journal of Managerial Auditing, 241-264. http://dx.doi.org/10.1108/02686900610652991

Qu, W., Cooper, B., Wise, V., \& Leung, P. (2012). Voluntary disclosure in a changing regulatory environment, evidence from Chinese stock market. International Journal of Economics and Finance, 4(4), 30-43. http://dx.doi.org/10.5539/ijef.v4n4p30

Reed, R., \& DeFillipi, R. (1990). Causal ambiguity, barriers to imitation and sustainable competitive advantage. Academy of Management Review, 15, 88-102.

Rose, C. (2005). The composition of semi-two-tier corporate boards and firm performance. Corporate Governance, 13(5), 691-701. http://dx.doi.org/10.1111/j.1467-8683.2005.00460.x

Said, R., Hj Zainuddin, Y., \& Haron, H. (2009). The relationship between corporate social responsibility disclosure and corporate governance characteristics in Malaysian public listed companies. Social Responsibility Journal, 5(2), 212-226. http://dx.doi.org/10.1108/17471110910964496

Shleifer, A., \& Vishny, R. (1997). A survey of corporate governance. Journal of Finance, 52, $737-783$. http://dx.doi.org/10.1111/j.1540-6261.1997.tb04820.x

Singh, V., Vinnicombe, S., \& Johnson, P. (2001). Women directors on top UK boards. Corporate Governance: An International Review, 9, 206-216. http://dx.doi.org/10.1111/1467-8683.00248

Singhvi, S., \& Desai, H. (1971). An empirical analysis of the quality of corporate financial disclosure. Accounting Review, 46(1), 129-138.

Solomon, J. (2010). Corporate governance and accountability (3rd ed.). John Wiley and Sons Publications.

Sonnenfeld, J. (2002). What makes great boards great? Harvard Business Review, 80(9), 106-114.

Uyar, A., Kilic, M., \& Bayyur, N. (2013). Association between firm characteristics and corporate voluntary disclosure: Evidence from Turkish listed companies. Intangible Capital, 9(4), 1080-1112. http://dx.doi.org/10.3926/ic.439

Van der Walt, N., Ingley, C., Shergill, G., \& Townsend, A. (2006). Board Configuration: Are Diverse Boards Better Boards? Corporate Governance: The Journal of Business in Society, 6(2), 129-147.

Van Ness, R., \& Seifert, C. (2007). Boards of directors and corporate performance: An analysis model. Journal of Business Research, 7(3), 11-21.

Verrecchia, R. (1983). Discretionary disclosure. Journal of Accounting and Economics, 5(3), $179-194$. http://dx.doi.org/10.1016/0165-4101(83)90011-3

Wang, K., Sewon, C., \& Claibone, M. (2008). Determinants and consequences of voluntary disclosure in an emerging market: Evidence from China. International Journal of Accounting, Auditing and Taxation, 17(1), 14-30. http://dx.doi.org/10.1016/j.intaccaudtax.2008.01.001

Watson, E., Kumar, K., \& Michaelsen, L. (1993). Cultural diversity's impact on interaction process and performance: comparing homogenous and diverse task groups. Academy of Management Journal, 36, 590-603. http://dx.doi.org/10.2307/256593 
Welker, M. (1995). Disclosure policy, information asymmetry, and liquidity in equity markets. Contemporary Accounting Research, 11(2), 801-827. http://dx.doi.org/10.1111/j.1911-3846.1995.tb00467.x

Xiao, H., \& Yuan, J. (2007). Ownership structure, board composition and corporate voluntary disclosure: evidence from listed firms in China. Managerial Auditing Journal, 22(6), 604-619. http://dx.doi.org/10.1108/02686900710759406

Yanesari, A., Gerayli, M., Ma'atoofi, A., \& Abadi, A. (2012). Board characteristics and corporate voluntary disclosure: An Iranian perspective. Archives Des Sciences, 64(5), 478-484.

Yuen, D., Liu, M., Zhang, X., \& Lu, C. (2009). A case study of voluntary disclosure by Chinese enterprises. Asian Journal of Finance \& Accounting, 1(2), 118-144.

Zajac, E., \& Westphal, J. (1996). Director reputation, CEO/board power, and the dynamics of board interlocks. Administrative Science Quarterly, 41, 507-529. http://dx.doi.org/10.2307/2393940

\section{Note}

Note 1 . There is a reference in Islam and other beliefs that 40 is the age of maturity and responsibility. For example, it is reported by many scholars that most prophets and messengers received their first revelation from Allah at the age of forty (Assoyotee, 1982). Furthermore, The Holy Qura'an in Surat Al-ahqaf (verse 15), refers to 40 as the age of responsibility, that being when the human reaches full maturity. The translation of verse 15: "And We have enjoined upon man, to his parents, good treatment. His mother carried him with hardship and gave birth to him with hardship, and his gestation and weaning [period] is thirty months. He grows until, when he reaches maturity and reaches the age of forty years, he says, My Lord, enable me to be grateful for Your favor which You have bestowed upon me and upon my parents and to work righteousness of which You will approve and make righteous for me my offspring. Indeed, I have repented to you".

\section{Copyrights}

Copyright for this article is retained by the author(s), with first publication rights granted to the journal.

This is an open-access article distributed under the terms and conditions of the Creative Commons Attribution license (http://creativecommons.org/licenses/by/3.0/). 